\title{
Influence of the Substitution Pattern (ortho vs para) on the Structure and Luminescence of Silver(I) Complexes Ligated by Diphenylphosphinobenzoic Acids
}

\author{
Ana B. Miguel-Coello and Manuel Bardají*
}

\author{
IU CINQUIMA/Química Inorgánica, Facultad de Ciencias, Universidad de Valladolid, E-47071 \\ Valladolid, Spain.
}

* Author to whom correspondence should be addressed: M.B.e-mail: bardaji@qi.uva.es

\section{ABSTRACT}

The reaction of $\mathrm{AgCF}_{3} \mathrm{SO}_{3}$ with diphenylphosphinobenzoic acids 10 leads to a cyclic dinuclear or a polynuclear silver(I) compound, depending on the relative position of phosphine versus carboxylic functional group. The dimers $\left[\mathrm{Ag}_{2}\left(\mathrm{OSO}_{2} \mathrm{CF}_{3}\right)_{2}(\mu-\mathrm{O}, \mathrm{P}-\right.$ $\left.\left.\mathrm{PPh}_{2} \mathrm{C}_{6} \mathrm{H}_{4} \mathrm{COOH}-\mathrm{O}\right)_{2}\right] \quad \mathbf{1}$ or $\quad\left[\left\{\mathrm{Ag}\left(\mu-\mathrm{O}, \mathrm{P}-\mathrm{PPh}_{2} \mathrm{C}_{6} \mathrm{H}_{4} \mathrm{COOH}-\right.\right.\right.$ o) $\left.\left.\left(\mathrm{OH}_{2}\right)_{2}\right\}_{2}\right]\left(\mathrm{CF}_{3} \mathrm{SO}_{3}\right)_{2} \cdot 2 \mathrm{CH}_{2} \mathrm{Cl}_{2} \quad \mathbf{1 a}$ are 12-membered 15 diargentacycles with a silver-silver distance of 3.982 or $3.754 \AA$, while the polymer $\left[\mathrm{Ag}_{\mathrm{n}}\left(\mathrm{OSO}_{2} \mathrm{CF}_{3}\right)_{\mathrm{n}}\left(\mu-\mathrm{O}, \mathrm{P}-\mathrm{PPh}_{2} \mathrm{C}_{6} \mathrm{H}_{4} \mathrm{COOH}-\right.\right.$ $\left.\mathrm{p})_{\mathrm{n}}\right] 2$ is a $1 \mathrm{D}$ type. The ligand is always acting as non-chelating bridge, being the silver center coordinated to the phosphine phosphorous, and one oxygen (carbonyl) of the carboxylic acid of 20 next fragment. One oxygen of the triflate anion or two water molecules complete the coordination sphere. Besides, p(diphenylphosphino)benzoic acid compound is emissive in solution and in the solid state at 298 and $77 \mathrm{~K}$, while compound with the ortho ligand is not. At $298 \mathrm{~K}$, the emissions are centered 25 at $471 \mathrm{~nm}$ in the solid state and at $416 \mathrm{~nm}$ in solution.

Keywords: 2-(diphenyphosphino)benzoic acid, 4(diphenyphosphino)benzoic acid, silver complexes, bridging ligand, luminescence, $\mathrm{X}$-ray crystal structure.

\section{Introduction}

30

A key strategy in the design and synthesis of metal-organic frameworks (MOF's) and other hybrid organic-inorganic molecular materials is the utilization of simple multifunctional building blocks that induce the formation of complex 35 molecular structures by self-assembly [1]. Silver (I) centers are particularly versatile as components of such building blocks because of their flexible coordination number and geometry [2], and the tendency to form $\mathrm{Ag} \cdots \mathrm{Ag}$ weak interactions [3]. Although there are many reports on other 40 luminescent $\mathrm{d}^{10}$-metal complexes, emissive $\mathrm{Ag}^{\mathrm{I}}$ complexes have been less studied because of their potential photosensitivity and limited luminescence [4]. In this respect, the potentially polydentate $o_{-}$and $p-$ (diphenylphosphino)benzoic acids are interesting ligands ${ }_{45}$ combining soft $(\mathrm{P})$ with hard $(\mathrm{O})$ donor atoms. Moreover, the carboxylic group is suitable to produce hydrogen bonds. In fact 2-diphenylphosphinobenzoic acid is a dimer with the typical H-bonds of carboxylic acids (Scheme 1) [5].

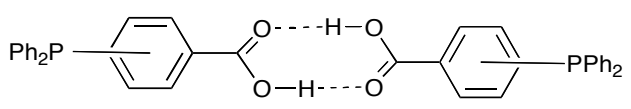

Scheme 1 . H-bonds between two carboxylic groups.

The ortho or para relative position of the phosphine versus the carboxylic acid can be used to engineer different three${ }_{55}$ dimensional geometries. For instance, the homoleptic gold complex of 2-(diphenylphosphino)benzoate is a mixture of a dimer and a trimer (a trimer is isolated as crystal), while the corresponding 4-(diphenylphosphino)benzoate complex is a polymer; in both cases, the ligands are working as $\mathrm{O}, \mathrm{P}-$ 60 bridges [6]. Homoleptic silver complex of 2(diphenylphosphino)benzoate is a hexanuclear compound with the ligand acting as tri- and tetradentate bridge [7]. Depending on the metal center, 2(diphenylphosphino)benzoate ligand leads to dimers via ${ }_{65}$ carboxylate or $\mathrm{O}, \mathrm{P}$-bridges, or to mononuclear compounds acting as $\mathrm{O}, \mathrm{P}$-chelate (Scheme 2) [8]. 4(diphenylphosphino)benzoate evolves again to a dimer with carboxylate bridges, which can be additionally bonded through the phosphorus atom; besides, polynuclear derivatives 70 can be obtained by O, P-bridges (Scheme 2) [9]. a<smiles>[M]OC(=O)c1ccccc1PP</smiles>

c

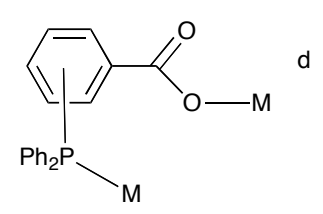

b<smiles>[M]OC(=O)c1cccc(P)c1</smiles>

d

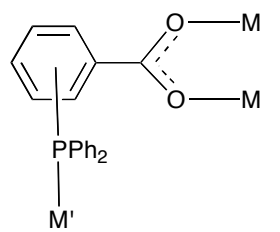

Scheme 2. a) Chelate for 2-(diphenylphosphino)benzoate; b) carboxylate bridges; c) O, P-bridges; d) more complex coordination mode (M' can be the same metal fragment).

The related chloro gold(I) derivatives of 2- or 4(diphenylphosphino)benzoic acid are dimers, by a 
symmetrical double $\mathrm{H}$-bond between the two carboxylic groups $[6,10]$. Similarly, $\mathrm{Cu}(\mathrm{I})$ complexes become dimers by a typical double carboxylic $\mathrm{H}$-bond [11]. However, chloro palladium(II) compounds with 4-(diphenylphosphinobenzoic) 5 acid are mononuclear with the carboxylic group making $\mathrm{H}-$ bonds with solvent crystallization molecules [12].

Here we report the synthesis and structural characterization of silver(I) compounds with 2- and 4-

10 (diphenylphosphino)benzoic acids, where the substitution pattern on the ligand leads to different nuclearities and luminescence properties on the complexes.

\section{Experimental}

For general procedures see Supplementary data.

\subsection{Synthesis of $\left[\mathrm{Ag}\left(\mathrm{OSO}_{2} \mathrm{CF}_{3}\right)\left(\mathrm{PPh}_{2} \mathrm{C}_{6} \mathrm{H}_{4} \mathrm{COOH}\right)\right]$; ortho (1), para (2).}

To a diethyl ether solution $(20 \mathrm{~mL})$ of $\mathrm{AgCF}_{3} \mathrm{SO}_{3}(51 \mathrm{mg}, 0.2$ mmol) was added the corresponding phosphinobenzoic acid $(61 \mathrm{mg}, 0.2 \mathrm{mmol})$, and the reaction stirred for $2 \mathrm{~h}$ protected from the light. The insoluble compounds were filtered off, 25 washed and dried. A second fraction was obtained by evaporation ca. $2 \mathrm{ml}$ and addition of hexane. Compounds 1-2 were obtained as white solids. Yield of 1: $78 \mathrm{mg}, 70 \%$. Anal. Calc. for $\mathrm{C}_{40} \mathrm{H}_{30} \mathrm{Ag}_{2} \mathrm{~F}_{6} \mathrm{O}_{10} \mathrm{P}_{2} \mathrm{~S}_{2}: \mathrm{C}, 42.65 ; \mathrm{H}, 2.68 ; \mathrm{N}, 0$. Found: $\mathrm{C}, 42.37 ; \mathrm{H}, 2.75 ; \mathrm{N}, 0 \% .{ }^{1} \mathrm{H}$ NMR $\left(\mathrm{d}_{6}\right.$-acetone): $\delta$ $308.37\left(\mathrm{~d}, \mathrm{~J}_{\mathrm{HH}}=7.6 \mathrm{~Hz}, 1 \mathrm{H}, \mathrm{H}^{6}\right), 7.76\left(\mathrm{td}, \mathrm{J}_{\mathrm{HH}}=7.6 \mathrm{~Hz}, \mathrm{~J}_{\mathrm{HP}}=\right.$ $\left.1.4 \mathrm{~Hz}, 1 \mathrm{H}, \mathrm{H}^{5}\right), 7.70\left(\mathrm{td}, \mathrm{J}_{\mathrm{HH}}=7.6 \mathrm{~Hz}, \mathrm{~J}_{\mathrm{HP}}=1.4 \mathrm{~Hz}, 1 \mathrm{H}, \mathrm{H}^{4}\right)$, $7.59-7.45(\mathrm{~m}, 10 \mathrm{H}, \mathrm{Ph}), 7.04\left(\mathrm{t}, \mathrm{J}_{\mathrm{HP}}=\mathrm{J}_{\mathrm{HH}}=7.8 \mathrm{~Hz}, 1 \mathrm{H}, \mathrm{H}^{3}\right)$. ${ }^{1} \mathrm{H}$ NMR $\left(-50^{\circ} \mathrm{C}, \mathrm{d}_{6}\right.$-acetone): $\delta 12.49$ (brs, $\left.1 \mathrm{H}, \mathrm{COOH}\right), 8.40$ (ddd, $\mathrm{J}_{\mathrm{HH}}=7.5$ and $\left.1.5 \mathrm{~Hz}, \mathrm{~J}_{\mathrm{HP}}=4.4 \mathrm{~Hz}, 1 \mathrm{H}, \mathrm{H}^{6}\right), 7.82\left(\mathrm{t}, \mathrm{J}_{\mathrm{HH}}\right.$ $\left.{ }_{35}=7.5 \mathrm{~Hz}, 1 \mathrm{H}, \mathrm{H}^{5}\right), 7.77\left(\mathrm{t}, \mathrm{J}_{\mathrm{HH}}=7.5 \mathrm{~Hz}, 1 \mathrm{H}, \mathrm{H}^{4}\right), 7.60-7.43$ $(\mathrm{m}, 10 \mathrm{H}, \mathrm{Ph}), 6.94\left(\mathrm{ddd}, \mathrm{J}_{\mathrm{HP}}=9.2\right.$ and $1.2 \mathrm{~Hz}, \mathrm{~J}_{\mathrm{HH}}=7.5 \mathrm{~Hz}$, $\left.1 \mathrm{H}, \mathrm{H}^{3}\right) \cdot{ }^{19} \mathrm{~F}$ NMR $\left(\mathrm{d}_{6}\right.$-acetone): $-77.58(\mathrm{~s}) .{ }^{31} \mathrm{P}$ NMR $\left(\mathrm{d}_{6}-\right.$ acetone): 15.6 (brs). ${ }^{31} \mathrm{P}$ NMR $\left(-50^{\circ} \mathrm{C}, \mathrm{d}_{6}\right.$-acetone $): 15.5(\mathrm{~d}$, ${ }^{1} \mathrm{~J}_{107 \mathrm{Ag}-31 \mathrm{P}}=736$ and $\left.{ }^{1} \mathrm{~J}_{109 \mathrm{Ag}-31 \mathrm{P}}=849 \mathrm{~Hz}\right)$. IR $(\mathrm{KBr}): 3060$ ${ }_{40} v(\mathrm{O}-\mathrm{H}), 1673 \mathrm{v}(\mathrm{C}=\mathrm{O}), 1257,1223,1209,635\left(\mathrm{CF}_{3} \mathrm{SO}_{3}\right) \mathrm{cm}^{-1}$. Yield of 2: $91 \mathrm{mg}, 81 \%$. Anal. Calc. for $\mathrm{C}_{20} \mathrm{H}_{15} \mathrm{AgF}_{3} \mathrm{O}_{5} \mathrm{PS}$ : C, 42.65; H, 2.68; N, 0. Found: C, 42.60; H, 2.84; N, 0\%. ${ }^{1} \mathrm{H}$ NMR ( $\mathrm{d}_{6}$-acetone): $\delta 11.5$ (brs, $\left.1 \mathrm{H}, \mathrm{COOH}\right), 8.13\left(\mathrm{~d}, \mathrm{~J}_{\mathrm{HH}}=\right.$ $\left.8.0 \mathrm{~Hz}, 2 \mathrm{H}, \mathrm{H}^{2}\right), 7.68-7.55\left(\mathrm{~m}, 12 \mathrm{H}, \mathrm{H}^{3}+\mathrm{Ph}\right) .{ }^{1} \mathrm{H}$ NMR $(-$ ${ }_{45} 50^{\circ} \mathrm{C}, \mathrm{d}_{6}$-acetone): $\delta 12.54$ (brs, $\left.1 \mathrm{H}, \mathrm{COOH}\right), 8.15\left(\mathrm{dd}, \mathrm{J}_{\mathrm{HP}}\right.$ $\left.=1.6 \mathrm{~Hz}, \mathrm{~J}_{\mathrm{HH}}=8.4 \mathrm{~Hz}, 2 \mathrm{H}, \mathrm{H}^{2}\right), 7.68-7.53\left(\mathrm{~m}, 12 \mathrm{H}, \mathrm{H}^{3}+\mathrm{Ph}\right)$. ${ }^{19} \mathrm{~F}$ NMR $\left(\mathrm{d}_{6}\right.$-acetone $):-77.6(\mathrm{~s}) .{ }^{31} \mathrm{P}$ NMR $\left(\mathrm{d}_{6}\right.$-acetone $): 14.5$ $\left(\mathrm{d},{ }^{1} \mathrm{~J}_{\mathrm{Ag}-\mathrm{P}}=721 \mathrm{~Hz}\right) \cdot{ }^{31} \mathrm{P}$ NMR $\left(-50^{\circ} \mathrm{C}, \mathrm{d}_{6}\right.$-acetone $): 13.8(\mathrm{~d}$, ${ }^{1} \mathrm{~J}_{107 \mathrm{Ag}-31 \mathrm{P}}=690$ and $\left.{ }^{1} \mathrm{~J}_{109 \mathrm{Ag}-31 \mathrm{P}}=795 \mathrm{~Hz}\right)$. IR $(\mathrm{KBr}): 3054$ ${ }_{50} \mathrm{v}(\mathrm{O}-\mathrm{H}), 1687 \mathrm{v}(\mathrm{C}=\mathrm{O}), 1223,635\left(\mathrm{CF}_{3} \mathrm{SO}_{3}\right) \mathrm{cm}^{-1}$.

Table 1. Details of Crystal Data and Structure Refinement for Complexes 1, 1a and 2

\begin{tabular}{|c|c|c|c|}
\hline Compound & 1 & 1a & 2 \\
\hline Empirical formula & $\mathrm{C}_{40} \mathrm{H}_{30} \mathrm{Ag}_{2} \mathrm{~F}_{6} \mathrm{O}_{10} \mathrm{P}_{2} \mathrm{~S}_{2}$ & $\mathrm{C}_{42} \mathrm{H}_{42} \mathrm{Ag}_{2} \mathrm{Cl}_{4} \mathrm{~F}_{6} \mathrm{O}_{14} \mathrm{P}_{2} \mathrm{~S}_{2}$ & $\mathrm{C}_{20} \mathrm{H}_{15} \mathrm{AgF}_{3} \mathrm{O}_{5} \mathrm{PS}$ \\
\hline Formula weigth & 1126.44 & 1368.36 & 563.22 \\
\hline $\mathrm{T}(\mathrm{K})$ & $298(2)$ & $298(2)$ & $298(2)$ \\
\hline Wavelength $(\AA)$ & 0.71073 & 0.71073 & 0.71073 \\
\hline Crystal system & Triclinic & Triclinic & Monoclinic \\
\hline Space group & $\mathrm{P}-1$ & $\mathrm{P}-1$ & P $2{ }_{1} / \mathrm{n}$ \\
\hline Unit cell $\operatorname{dim} .: a(\AA)$ & $7.8319(5)$ & $10.5574(17)$ & $12.8706(11)$ \\
\hline$b(\AA)$ & $11.8958(10)$ & $11.4142(18)$ & $10.4407(5)$ \\
\hline$c(\AA)$ & $12.1326(11)$ & $13.1871(11)$ & $16.3978(10)$ \\
\hline$\alpha\left(\left(^{\circ}\right)\right.$ & $104.153(7)$ & $100.856(10)$ & 90 \\
\hline$\beta\left(^{\circ}\right)$ & $94.333(6)$ & $104.094(10)$ & $103.466(7)$ \\
\hline$\chi\left({ }^{\circ}\right)$ & $104.957(7)$ & $113.623(16)$ & 90 \\
\hline $\mathrm{V}\left(\AA^{3}\right)$ & $1047.25(14)$ & $1337.0(3)$ & $2142.9(3)$ \\
\hline $\mathrm{Z}$ & 1 & 1 & 4 \\
\hline $\mathrm{D}_{\text {calc }}\left(\mathrm{Mg} / \mathrm{m}^{3}\right)$ & 1.786 & 1.699 & 1.746 \\
\hline Abs. coeff. $\left(\mathrm{mm}^{-1}\right)$ & 1.195 & 1.151 & 1.168 \\
\hline $\mathrm{F}(000)$ & 560 & 684 & 1120 \\
\hline Crystal habit & Prism & Tablet & Plate \\
\hline Crystal size (mm) & $0.22 \times 0.09 \times 0.09$ & $0.33 \times 0.08 \times 0.06$ & $0.26 \times 0.17 \times 0.07$ \\
\hline$\Theta$ range for data colln & 2.72 to 28.62 & 2.06 to 27.83 & 2.29 to 28.76 \\
\hline Index ranges & $\begin{array}{c}-10<=\mathrm{h}<=6, \\
-15<=\mathrm{k}<=15, \\
-14<=\mathrm{k}<=16\end{array}$ & $\begin{array}{l}-12<=\mathrm{h}<=13, \\
-11<=\mathrm{k}<=13, \\
-17<=\mathrm{l}<=15\end{array}$ & $\begin{array}{c}-11<=\mathrm{h}<=16, \\
-12<=\mathrm{k}<=13, \\
-21<=1<=16\end{array}$ \\
\hline Reflections collected & 7061 & 7344 & 8575 \\
\hline Independent reflections & $4310[\mathrm{R}(\mathrm{int})=0.0196]$ & $5341[\mathrm{R}(\mathrm{int})=0.0256]$ & $4474[\mathrm{R}(\mathrm{int})=0.0226]$ \\
\hline Maximum and minimum transmissions & 1.000 and 0.707 & 0.943 and 0.803 & 0.933 and 0.797 \\
\hline Data/restraints/parameters & $4310 / 0 / 290$ & $5341 / 1 / 325$ & 4474 / 0 / 280 \\
\hline Goodness-of-fit on $F^{2}$ & 1.047 & 1.022 & 1.024 \\
\hline Final $R$ indices $[I>2 \sigma(I)]$ & \multirow{2}{*}{\multicolumn{3}{|c|}{$\begin{array}{l}\mathrm{R} 1=0.0384, \mathrm{wR} 2=0.0704 \mathrm{R} 1=0.0669, \mathrm{wR} 2=0.1428 \mathrm{R} 1=0.0480, \mathrm{wR} 2=0.1083 \\
\mathrm{R} 1=0.0566 \mathrm{wR} 2=0.0786 \mathrm{R} 1=0.1243 . \mathrm{wR} 2=0.1801 \mathrm{R} 1=0.0699 . \mathrm{wR} 2=0.1204\end{array}$}} \\
\hline$R$ indices (all data) & & & \\
\hline Largest difference in peak and hole (e $\AA$ & 0.682 and -0.470 & 0.823 and -0.716 & 0.603 and -0.598 \\
\hline
\end{tabular}

2.2. Crystal structure determination of compounds 1,1 a and 2 .

The crystal was mounted on a glass fiber and transferred to the SuperNova Oxford Diffraction diffractometer. Crystal data and details of data collection and structure refinement are given in Table 1. Cell parameters, data reduction and ${ }_{60}$ absorption corrections were carried out with the CrysAlis 
system software [13]. The structure was refined anisotropically on $\mathrm{F}^{2}$ [14]. All non-hydrogen atomic positions were located in difference Fourier maps and refined anisotropically. The hydrogen atoms were placed in their ${ }_{5}$ geometrically generated positions. The presence of residual electronic density in monocrystal $\mathbf{1}$ that cannot be taken into account by displacement parameters shows some delocalisation of the silver ions around the main site. To describe it, a second position (Ag1B) is introduced. The 10 refinement of the occupancy of both sites leads to an overall composition of 0.935 mainly located on the first one. $\mathrm{H}$ of water in 1a were localized in Fourier maps, then the water molecules were refined as rigid units (1a is: [ $\{\mathrm{Ag}(\mu-\mathrm{O}, \mathrm{P}-$ $\left.\left.\left.\left.\mathrm{PPh}_{2} \mathrm{C}_{6} \mathrm{H}_{4} \mathrm{COOH}-\mathrm{O}\right)\left(\mathrm{OH}_{2}\right)_{2}\right\}_{2}\right]\left(\mathrm{CF}_{3} \mathrm{SO}_{3}\right)_{2} \cdot 2 \mathrm{CH}_{2} \mathrm{Cl}_{2}\right)$. The
15 triflate anion of monocrystal $\mathbf{2}$ is 'incipiently' disordered.

Table 1. Details of Crystal Data and Structure Refinement for Complexes 1, 1a and 2.

\begin{tabular}{|c|c|c|c|}
\hline Compound & 1 & $1 \mathrm{a}$ & 2 \\
\hline Empirical formula & $\mathrm{C}_{40} \mathrm{H}_{30} \mathrm{Ag}_{2} \mathrm{~F}_{6} \mathrm{O}_{10} \mathrm{P}_{2} \mathrm{~S}_{2}$ & $\mathrm{C}_{42} \mathrm{H}_{42} \mathrm{Ag}_{2} \mathrm{Cl}_{4} \mathrm{~F}_{6} \mathrm{O}_{14} \mathrm{P}_{2} \mathrm{~S}_{2}$ & $\mathrm{C}_{20} \mathrm{H}_{15} \mathrm{AgF}_{3} \mathrm{O}_{5} \mathrm{PS}$ \\
\hline Formula weigth & 1126.44 & 1368.36 & 563.22 \\
\hline $\mathrm{T}(\mathrm{K})$ & $298(2)$ & $298(2)$ & $298(2)$ \\
\hline Wavelength $(\AA)$ & 0.71073 & 0.71073 & 0.71073 \\
\hline Crystal system & Triclinic & Triclinic & Monoclinic \\
\hline Space group & $\mathrm{P}-1$ & $\mathrm{P}-1$ & $\mathrm{P} 22_{1} / \mathrm{n}$ \\
\hline Unit cell dim.: $a(\AA)$ & $7.8319(5)$ & $10.5574(17)$ & $12.8706(11)$ \\
\hline$b(\AA)$ & $11.8958(10)$ & $11.4142(18)$ & $10.4407(5)$ \\
\hline$c(\AA)$ & $12.1326(11)$ & 13.1871(11) & $16.3978(10)$ \\
\hline$\alpha\left({ }^{\circ}\right)$ & $104.153(7)$ & $100.856(10)$ & 90 \\
\hline$\beta\left(^{\circ}\right)$ & $94.333(6)$ & 104.094(10) & $103.466(7)$ \\
\hline$\chi\left({ }^{\circ}\right)$ & $104.957(7)$ & $113.623(16)$ & 90 \\
\hline $\mathrm{V}\left(\AA^{3}\right)$ & $1047.25(14)$ & $1337.0(3)$ & $2142.9(3)$ \\
\hline Z & 1 & 1 & 4 \\
\hline $\mathrm{D}_{\text {calc }}\left(\mathrm{Mg} / \mathrm{m}^{3}\right)$ & 1.786 & 1.699 & 1.746 \\
\hline Abs. coeff. $\left(\mathrm{mm}^{-1}\right)$ & 1.195 & 1.151 & 1.168 \\
\hline $\mathrm{F}(000)$ & 560 & 684 & 1120 \\
\hline Crystal habit & Prism & Tablet & Plate \\
\hline Crystal size (mm) & $0.22 \times 0.09 \times 0.09$ & $0.33 \times 0.08 \times 0.06$ & $0.26 \times 0.17 \times 0.07$ \\
\hline$\Theta$ range for data colln & 2.72 to 28.62 & 2.06 to 27.83 & 2.29 to 28.76 \\
\hline Index ranges & $\begin{array}{c}-10<=\mathrm{h}<=6, \\
-15<=\mathrm{k}<=15, \\
-14<=1<=16\end{array}$ & $\begin{array}{l}-12<=\mathrm{h}<=13, \\
-11<=\mathrm{k}<=13, \\
-17<=\mathrm{l}<=15\end{array}$ & $\begin{array}{c}-11<=\mathrm{h}<=16, \\
-12<=\mathrm{k}<=13, \\
-21<=1<=16\end{array}$ \\
\hline Reflections collected & 7061 & 7344 & 8575 \\
\hline Independent reflections & $4310[\mathrm{R}(\mathrm{int})=0.0196]$ & $5341[\mathrm{R}(\mathrm{int})=0.0256]$ & $4474[\mathrm{R}(\mathrm{int})=0.0226]$ \\
\hline Maximum and minimum transmissions & 1.000 and 0.707 & 0.943 and 0.803 & 0.933 and 0.797 \\
\hline Data/restraints/parameters & $4310 / 0 / 290$ & $5341 / 1 / 325$ & $4474 / 0$ / 280 \\
\hline Goodness-of-fit on $F^{2}$ & 1.047 & 1.022 & 1.024 \\
\hline Final $R$ indices $[I>2 \sigma(I)]$ & \multicolumn{3}{|c|}{$\mathrm{R} 1=0.0384, \mathrm{wR} 2=0.0704 \mathrm{R} 1=0.0669, \mathrm{wR} 2=0.1428 \mathrm{R} 1=0.0480, \mathrm{wR} 2=0.1083$} \\
\hline$R$ indices (all data) & \multicolumn{3}{|c|}{$\mathrm{R} 1=0.0566, \mathrm{wR} 2=0.0786 \mathrm{R} 1=0.1243, \mathrm{wR} 2=0.1801 \mathrm{R} 1=0.0699, \mathrm{wR} 2=0.1204$} \\
\hline Largest difference in peak and hole (e $\AA^{-}$ & 0.682 and -0.470 & 0.823 and -0.716 & 0.603 and -0.598 \\
\hline
\end{tabular}

\section{Results and discussion}

35 3.1. Synthesis and characterization 
The reaction of silver(I) triflate with $2-$ and 4(diphenylphosphino)benzoic acid in a 1:1 molar ratio (Scheme 3) yields $\left[\mathrm{Ag}\left(\mathrm{OSO}_{2} \mathrm{CF}_{3}\right)\left(\mathrm{PPh}_{2} \mathrm{C}_{6} \mathrm{H}_{4} \mathrm{COOH}\right)\right]$.

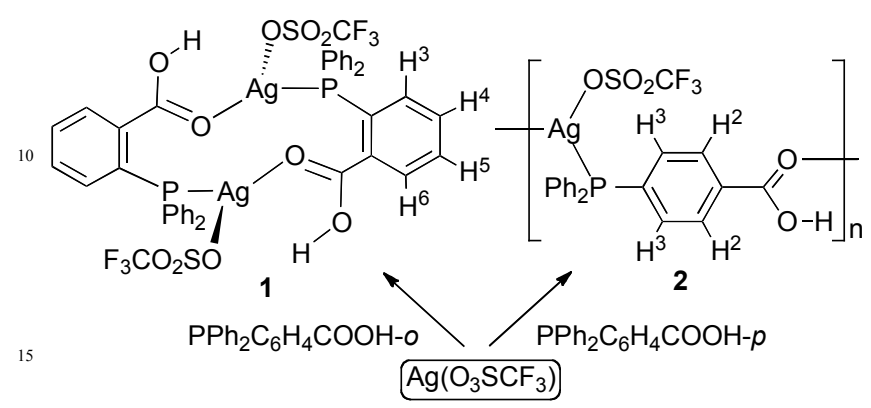

Scheme 3. Preparation of compounds.

Compounds $\mathbf{1}-\mathbf{2}$ are air-stable white solids at room 20 temperature, and were characterized by elemental analysis, IR and NMR spectroscopy. The complexes display one $v(C=O)$ band from the carboxylic group at about $1680 \mathrm{~cm}^{-1}$, and a broad $v(\mathrm{O}-\mathrm{H})$ band at about $3060 \mathrm{~cm}^{-1}$. In their ${ }^{1} \mathrm{H}$ NMR spectra, the aromatic benzoic protons are slightly shifted ${ }_{25}$ compared to the free phosphine ligand. The largest shifts are about $+0.27 \mathrm{ppm}$ for $\mathrm{H}^{5}$ in the ortho ligand, and $+0.28 \mathrm{ppm}$ for $\mathrm{H}^{3}$ in the para ligand. The assignment was confirmed by COSY and ${ }^{1} \mathrm{H}\left\{{ }^{31} \mathrm{P}\right\}$ NMR spectra. The ${ }^{19} \mathrm{~F}$ NMR spectra show a singlet at about $-78 \mathrm{ppm}$ because of the triflate anion. A 30 broad resonance for the coordinated phosphine, because of unresolved coupling to the two silver isotopes, was observed in the ${ }^{31} \mathrm{P}\left\{{ }^{1} \mathrm{H}\right\}$ NMR spectra of compound $\mathbf{1}$, while for compound 2 a doublet is seen. The resonance is low-field shifted about $19 \mathrm{ppm}$ for compounds compared to the free

${ }_{35}$ phosphine ligand. At $-50{ }^{\circ} \mathrm{C}$, the two $\mathrm{Ag}-\mathrm{P}$ couplings are resolved and two doublets are observed centered at $15.5 \mathrm{ppm}$ $\left({ }^{1} \mathrm{~J}_{107 \mathrm{Ag}-31 \mathrm{P}}=736 \mathrm{~Hz},{ }^{1} \mathrm{~J}_{109 \mathrm{Ag}-31 \mathrm{P}}=849 \mathrm{~Hz}\right)$ for complex $\mathbf{1}$, and $13.8\left({ }^{1} \mathrm{~J}_{107 \mathrm{Ag}-31 \mathrm{P}}=690 \mathrm{~Hz},{ }^{1} \mathrm{~J}_{109 \mathrm{Ag}-31 \mathrm{P}}=795 \mathrm{~Hz}\right)$ for 2 .

\section{3.2. Solid-state structures}

The solid-state structures of compounds $\mathbf{1}$ and $\mathbf{2}$ were solved by single-crystal $\mathrm{X}$-ray diffraction studies and confirmed the bridging coordination of diphenylphosphinobenzoic acid. The 45 crystals studied were obtained by slow diffusion of petroleum ether $\left(60-95^{\circ}\right)$ into a solution of $\mathbf{1}$ in acetone/toluene or $\mathbf{2}$ in acetone at $-18^{\circ} \mathrm{C}$. By slow evaporation of a diethyl ether solution of $\mathbf{1}$, the same single crystals were obtained, which was verified by determining the unit cell. Slow diffusion of 50 hexane into a solution of $\mathbf{1}$ in dichloromethane at $-18^{\circ} \mathrm{C}$ led to a different complex, denoted as $\mathbf{1 a}$ and being its formula: $\left[\left\{\mathrm{Ag}\left(2-\mathrm{PPh}_{2} \mathrm{C}_{6} \mathrm{H}_{4} \mathrm{COOH}\right)\left(\mathrm{OH}_{2}\right)_{2}\right\}_{2}\right]\left(\mathrm{CF}_{3} \mathrm{SO}_{3}\right)_{2} \cdot 2 \mathrm{CH}_{2} \mathrm{Cl}_{2}$.

Compounds $\mathbf{1}$ and $\mathbf{1 a}$ crystallized as a $\mathrm{P}-1$ triclinic single crystal, while compound 2 crystallized as a $\mathrm{P} 2{ }_{1} / \mathrm{n}$ monoclinic ${ }_{55}$ single crystal. The structures are shown in Figures $1-3$, with selected bond lengths and angles in Table 2. The asymmetric unit of $\mathbf{1}$ and $\mathbf{2}$ contained the fragment $\mathrm{Ag}\left(\mathrm{OSO}_{2} \mathrm{CF}_{3}\right)\left(\mathrm{PPh}_{2} \mathrm{C}_{6} \mathrm{H}_{4} \mathrm{COOH}\right)$, with the silver center coordinated to the phosphine through the $\mathrm{P}$ atom and to the
60 triflate anion via an oxygen. On the other hand, the asymmetric unit of 1a displayed the fragment $\left[\mathrm{Ag}\left(\mathrm{OH}_{2}\right)_{2}\left(\mathrm{PPh}_{2} \mathrm{C}_{6} \mathrm{H}_{4} \mathrm{COOH}\right)\right]\left(\mathrm{CF}_{3} \mathrm{SO}_{3}\right)$, again with the silver center coordinated to the phosphine through the $\mathrm{P}$ atom, but now is coordinated to two water molecules (loosely to one) ${ }_{65}$ via their oxygen atom and with free triflate anion. The silver center is coordinated to another oxygen atom in the three structures: the carbonyl of the carboxylic acid of another equal fragment. Therefore, the ligand is always acting as a bidentate non-chelating bridge. In that way the ortho benzoic 70 acid leads to a cyclic dimer, which consists of a $12-$ membered dimetallacycle with tri- or tetracoordinated silver centers. On the other hand, the para benzoic acid leads to a $1 \mathrm{D}$-polymer because of the relative position of the carboxylic and the phosphine functional groups. The close compound $\left[\mathrm{Ag}_{6}(\mathrm{O}-\right.$ $\left.{ }_{75} \mathrm{PPh}_{2} \mathrm{C}_{6} \mathrm{H}_{4} \mathrm{COO}\right)_{6}$ ] shows two silver triangles (Ag- $\mathrm{Ag}$ distances of $3.244,3.756$ and $3.805 \AA$ ) related by a symmetry center, with the anionic ligand acting as tri- or tetradentate non-chelating bridge [7].

80 Table 2. Selected Bond Lengths $[\AA]$ and Angles [deg] for Complexes 1, $1 \mathrm{a}$ and 2.

\begin{tabular}{llll} 
& $\mathbf{1}$ & $\mathbf{1 a}$ & $\mathbf{2}$ \\
\hline $\mathrm{Ag}-\mathrm{P}$ & $2.4127(9)$ & $2.3623(16)$ & $2.3617(11)$ \\
$\mathrm{Ag}-\mathrm{O}$ & $2.482(2)$ & $2.362(5)$ & $2.272(3)$ \\
(carbox.) & & & \\
Ag-O & $2.318(3)$ & - & $2.398(5)$ \\
(triflate) & & & \\
Ag-O & - & $2.2474(18)$ & - \\
(water) & & $2.7187(19)$ & \\
$\mathrm{O}=\mathrm{C}$ & $1.211(4)$ & $1.207(8)$ & $1.200(5)$ \\
$\mathrm{O}-\mathrm{C}$ & $1.308(4)$ & $1.315(8)$ & $1.308(5)$ \\
$\mathrm{P}-\mathrm{Ag}-\mathrm{O}$ & $129.09(8)$ & - & $129.77(12)$ \\
(triflate) & & $136.18(8)$ & - \\
$\mathrm{P}-\mathrm{Ag}-\mathrm{O}$ & - & $100.46(6)$ & \\
(water) & & & \\
$\mathrm{P}-\mathrm{Ag}-\mathrm{O}$ & $112.49(6)$ & $138.09(13)$ & $146.08(11)$ \\
(carbox.) & & & \\
$\mathrm{O}-\mathrm{Ag}-\mathrm{O}$ & $97.07(9)$ & $80.02(13)$ & $78.34(17)$ \\
& & $84.46(6)$ & \\
& & $85.74(13)$ & \\
C-O-C & $123.6(3)$ & $122.8(6)$ & $123.1(4)$ \\
$\mathrm{C}-\mathrm{P}-\mathrm{Ag}$ & $108.65(10)$ & $107.3(2)$ & $112.05(12)$ \\
& $114.49(10)$ & $116.7(2)$ & $114.52(14)$ \\
& $118.66(10)$ & $119.92(19)$ & $116.51(14)$ \\
\hline
\end{tabular}

The silver atom of compound $\mathbf{1}$ displays a distorted trigonal geometry, with a large $\mathrm{P}-\mathrm{Ag}-\mathrm{O}$ (triflate) angle of $129.09(8)^{\circ}$, 85 and smaller $\mathrm{P}-\mathrm{Ag}-\mathrm{O}$ (carboxylic) and $\mathrm{O}-\mathrm{Ag}-\mathrm{O}$ angles of 112.49(6) and $97.07(9)^{\circ}$, respectively. However, the silver atom of compound 1a displays a highly distorted tetrahedral geometry, with a large $\mathrm{P}-\mathrm{Ag}-\mathrm{O}$ (carboxylic) angle of $138.09(13)^{\circ}$, smaller $\mathrm{P}-\mathrm{Ag}-\mathrm{O}$ (water) angles of $136.18(8)$ and $90100.46(6)^{\circ}$, and the smallest angles are $\mathrm{O}-\mathrm{Ag}-\mathrm{O}: 80.02(13)$, $84.46(6)$ and $85.74(13)^{\circ}$. On the other hand, the silver atom of compound 2 shows a highly distorted trigonal geometry, being the largest angle of $146.08(11)^{\circ}$ corresponding to $\mathrm{P}-\mathrm{Ag}-\mathrm{O}$ (carboxylic); there is an intermediate angle $\mathrm{P}-\mathrm{Ag}-\mathrm{O}$ (triflate) 95 of $129.77(12)^{\circ}$, and a small angle of $78.34(17)^{\circ}$ for $\mathrm{O}-\mathrm{Ag}-\mathrm{O}$. The Ag-O (triflate) distance found for $\mathbf{1}(2.318(3) \AA)$ is slightly shorter than found for 2 (2.398(5) $\AA$ ). However, the Ag-O (carboxylic) distance of 1 (2.482(2) Å) is slightly longer than found for 1a $(2.362(5) \AA)$, and both are longer 100 than found for $2(2.272(3) \AA)$. For 1a there is a short and a 
long Ag-O (water) distances of 2.2474(18) and 2.7187(19) $\AA$, respectively. Finally, the $\mathrm{Ag}-\mathrm{P}$ distance observed for $\mathbf{1}$ is slightly longer than observed for 1a or 2: 2.4127(9) versus $2.3623(16)$ or $2.3617(11) \AA$. The related derivative $\left[\mathrm{Ag}_{6}(\mathrm{o}-\right.$ $\left.{ }_{5} \mathrm{PPh}_{2} \mathrm{C}_{6} \mathrm{H}_{4} \mathrm{COO}\right)_{6}$ ] displays $\mathrm{Ag}-\mathrm{P}$ intermediate distances in the range 2.376(4)-2.381(4) $\AA$, while displays a short Ag-O (carboxylate) distance $(2.176(9)-2.261(9) \AA)$ and one or two longer Ag-O (carboxylate) distances from 2.394(9) to 2.619(9) A per silver(I) center (in the asymmetric unit there is 10 one tetracoordinate and two tricoordinate silver atoms) [7].

The intramolecular silver-silver distances are 3.982 (compound 1) and 3.754 (compound 1a) $\AA$, long to be considered as an $\mathrm{Ag} \cdots \mathrm{Ag}$ interaction (typically in the range 2.88-3.44 A: from metallic distance to sum of van der Waals 15 radii [3]. The shortest nonbonding intermolecular $\mathrm{Ag}-\mathrm{Ag}$ distance is $7.832 \AA$ for dimer $\mathbf{1}, 8.213 \AA$ for dimer 1a, while the shortest $\mathrm{Ag}-\mathrm{Ag}$ distance for polymer 2 is $4.467 \AA$. In addition, the $\mathrm{O}-\mathrm{H}$ of the carboxylic functional group forms an intramolecular $\mathrm{H}$-bond with an oxygen of the coordinated 20 triflate anion for $\mathbf{1}$ or with the loosely coordinated water for 1a (Table 3). Therefore, there are two equal $\mathrm{H}$-bonds per dimer. Similarly, compound $\mathbf{2}$ forms an additional donor Hbond between the $\mathrm{O}-\mathrm{H}$ and an oxygen of another triflate (of a second monomer), and also forms the symmetrical acceptor ${ }_{25} \mathrm{H}$-bond between an oxygen of its triflate and the $\mathrm{O}-\mathrm{H}$ of the same second monomer. In this way, each monomer of the 1D polymer associates doubly to another monomer of next polymer chain, leading to a double chain polymer (Supplementary Information). This structure demonstrates the 30 remarkable ability of silver(I) to form double polymeric structures through $\mathrm{H}$-bonding. Besides, longer $\mathrm{H}$-bonds can be proposed for structures $\mathbf{1}, \mathbf{1 a}$ and $\mathbf{2}$ (see Tables in Supplementary Information).

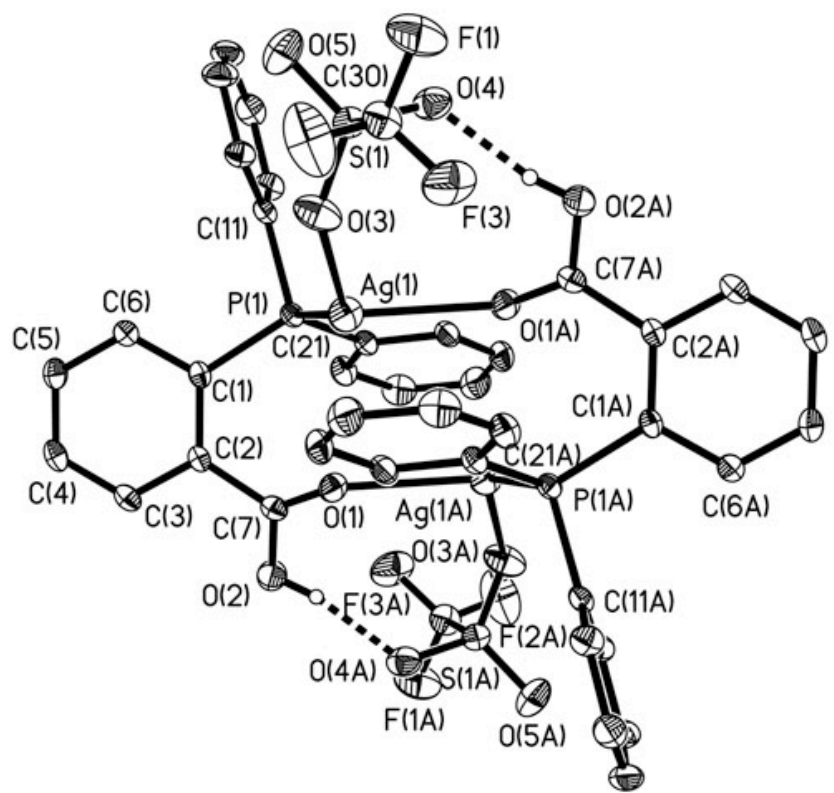

Figure 1. Structure of the dimeric molecule of compound 1. Ellipsoids are at $25 \%$ probability level ( $\mathrm{H}$ atoms omitted except carboxylic groups).
$\left[\mathrm{AuCl}\left(\mathrm{PPh}_{2} \mathrm{C}_{6} \mathrm{H}_{4} \mathrm{COOH}\right)\right]$ are monomers, which display a typical linear coordination for gold, being the free carboxylic acid groups associated by a double symmetric $\mathrm{H}$-bond to give dimers, the same for the ortho and the para ligands $[6,10]$.

45 The explanation must be related to the fact that the hard donor oxygen atom of the carbonyl group bonds stronger for silver than for gold, and also to the tendency of silver(I) to higher coordination numbers than gold(I).

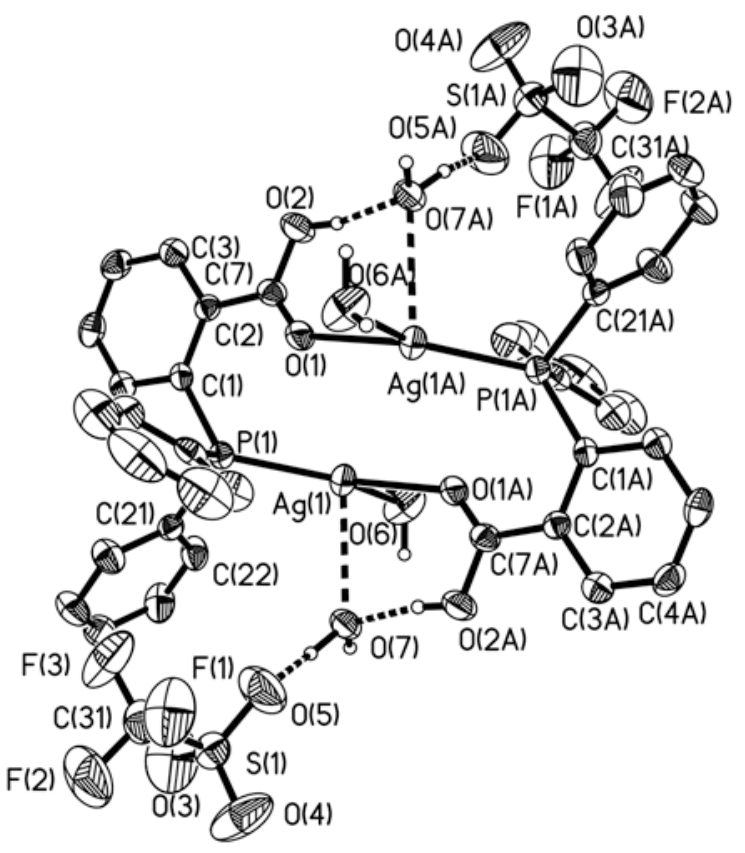

${ }_{50}$ Figure 2. Structure of the dimeric cation of compound 1a. Ellipsoids are at $30 \%$ probability level ( $\mathrm{H}$ atoms omitted except carboxylic groups). 
Figure 3. Polymeric structure of compound 2. Additional black lines to show the polymer growth. Ellipsoids are at $25 \%$ probability (most $\mathrm{H}$ atoms omitted for clarity): above, two consecutive units of the 1D chain ( $\mathrm{Ag}-\mathrm{O}$ bonds); below, fragment showing inter-chains $\mathrm{H}-$ bonds, giving 5 rise to double chains.

Table 3. Hydrogen Bonds for Dimers 1 and 1a and polymer $2[\AA$ and deg] involving the carboxylic group.

\begin{tabular}{|c|c|c|c|c|}
\hline D-H $\cdots A$ & $d(D-H)$ & $\mathrm{d}(\mathrm{H} \ldots \mathrm{A})$ & $\mathrm{d}(\mathrm{D} \ldots \mathrm{A})$ & $<$ (DHA) \\
\hline \multicolumn{5}{|l|}{ Compound 1} \\
\hline $\mathrm{O}(2)-\mathrm{H}(2) \cdots \mathrm{O}(4 \mathrm{~A})$ & 0.820 & 1.839 & 2.646 & 168.39 \\
\hline $\mathrm{O}(2 \mathrm{~A})-\mathrm{H}(2 \mathrm{~A}) \cdots \mathrm{O}(4)$ & 0.820 & 1.839 & 2.646 & 168.39 \\
\hline \multicolumn{5}{|l|}{ Compound 1a } \\
\hline $\mathrm{O}(2)-\mathrm{H}(2) \cdots \mathrm{O}(7 \mathrm{~A})$ & 0.820 & 1.819 & 2.610 & 161.69 \\
\hline $\mathrm{O}(2 \mathrm{~A})-\mathrm{H}(2 \mathrm{~A}) \cdots \mathrm{O}(7)$ & 0.820 & 1.819 & 2.610 & 161.69 \\
\hline \multicolumn{5}{|l|}{ Compound 2} \\
\hline $\mathrm{O}(1)-\mathrm{H}(1) \cdots \mathrm{O}(4 \mathrm{~A})$ & 0.820 & 1.828 & 2.626 & 164.09 \\
\hline $\mathrm{O}(1 \mathrm{~A})-\mathrm{H}(1 \mathrm{~A}) \cdots \mathrm{O}(4)$ & 0.820 & 1.828 & 2.626 & 164.09 \\
\hline
\end{tabular}

Symmetry transformations used to generate equivalent atoms: for 10 compound 1 are $1-x, 2-y, 1-z$; for compound $1 \mathbf{a}$ are $-\mathrm{x},-\mathrm{y}, 1-\mathrm{z}$; for compound 2 are $1-\mathrm{x}, 2-\mathrm{y}, 1-\mathrm{z}$.

The powder X-ray diffraction (XRD) patterns of compounds 1 and $\mathbf{2}$ are in good agreement with that simulated from the 15 corresponding single-crystal diffraction data (see Supplementary Information) confirming that the latter accurately represents the structure of the bulk solid (and not 1a).

\section{3.3. Luminescence studies}

The emission and excitation spectra of the free ligands and the silver complexes were recorded in the solid-state and in $\mathrm{CH}_{2} \mathrm{Cl}_{2}$ solution, at $298 \mathrm{~K}$ and $77 \mathrm{~K}$. The spectra of compound ${ }_{25} 2$ at $298 \mathrm{~K}$ are shown in Figure 4. The 4(diphenylphosphino)benzoic compound $\mathbf{2}$ and the corresponding free ligand emit, while the 2(diphenylphosphino)benzoic acid and its derivative $\mathbf{1}$ are nonemissive. The emission maximum in the solid state is at 471 $30 \mathrm{~nm}$ at $298 \mathrm{~K}$, similar to the free ligand $(474 \mathrm{~nm})$, but at 457 $\mathrm{nm}$ at $77 \mathrm{~K}$, blue-shifted compared to the free ligand $(479 \mathrm{~nm})$ and to $298 \mathrm{~K}$ emission. This emission could be assigned as ligand centered, although slightly modified by the metal fragment. Compound 2 shows an emission in $\mathrm{CH}_{2} \mathrm{Cl}_{2}$ solution 35 at $298 \mathrm{~K}$ centered at $416 \mathrm{~nm}$, while compound $\mathbf{1}$ and the two free ligands are non-emissive. At $77 \mathrm{~K}$ the emission maximum show little change, and is observed at $420 \mathrm{~nm}$, blue-shifted compared to the corresponding free ligand emission $(486 \mathrm{~nm})$. Emission peaks of compound $\mathbf{2}$ are 40 strongly blue-shifted compared to these observed in the solid state. Again, the emission could be assigned as ligand centered modified by the silver fragment.

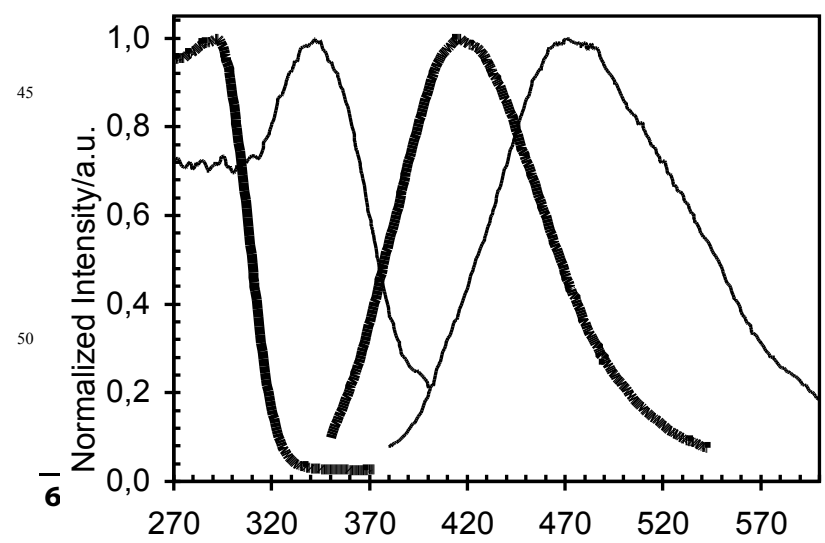

Figure 4. Solid state (regular line) and dichloromethane solution (bold line) excitation and emission spectra of compound 2 at $298 \mathrm{~K}$. 60

\section{Conclusions}

2- or 4-(diphenylphosphino)benzoic acids act as nonchelating bridge to give di- or polymeric silver(I) compounds, ${ }_{65}$ respectively, demonstrating that different geometrical orientation of the substituent induces entirely different connectivity patterns. The triflate anion or water molecules complete the coordination sphere. On the one hand, the carboxylic functional group is bridging monomers, on the 70 other hand is making H-bonds: intramolecularly for the dimer, and associating 1D chains in pairs for the polymer. Besides, the $p$-(diphenylphosphino) benzoic ligand and its corresponding silver complex are emissive, while the ortho ligand and complex are non-emissive.

75

\section{Acknowledgements}

We thank the Spanish Comisión Interministerial de Ciencia y Tecnología (Project CTQ2011-25137) and the Junta de Castilla y León (Project VA302U13) for financial support.

80

\section{Appendix A. Supplementary material}

CCDC 1004945-1004947 contains the supplementary crystallographic data for this paper. These data can be obtained free of charge from The Cambridge Crystallographic ${ }_{85}$ Data Centre via www.ccdc.cam.ac.uk/data request/cif. Supplementary data associated with this article can be found, in the online version, at doi: $\mathrm{xxx}$.

\section{References}

[1] (a) S. Leininger, B. Olenyuk, P. J. Stang, Chem. Rev. 100 (2000) 853; (b) G. Ferey, Chem. Soc. Rev. 37 (2008) 191. (c) G. A. Santillan, C. J. Carrano, Cryst. Growth Des. 9 (2009) 1590; (d) J. Ni, K.-J. Wei, Y. Liu, X.-C. Huang, D. Li, Cryst. Growth Des. 10 (2010) 3964; (e) A. M. Kirillov, S. W. Wieczorek, M. F. C. Guedes da Silva, J. Krol, Z. Staroniewicz, P. Smolenski, A. J. L. Pombeiro, Cryst. Growth Des. 11 (2011) 2711; (f) X.-L. Wang, Q. Gao, A.-X. Tian, G.-C. Liu, Cryst. Growth Des. 12 (2012) 2346; (g) L. Cunha-Silva, M. J. Carr, J. D. Kennedy, M. J. Hardie, Cryst. Growth Des. 13 (2013) 3162.

[2] (a) A. Laguna, M. C. Gimeno, Silver and Gold In Comprehensive Coordination Chemistry II: From Biology to Nanotechnology McCleverty, J. A., Meyer, T. J., Eds.; Elsevier, Oxford, UK, 2003; Vol. 6, Transition Metal Groups 9-12, Fenton, D. E., ed. Chapter 6.7, p. 911; (b) J.-R. Li, R.-H. Zhang, X.-H. Bu, Cryst. Growth Des. 3 (2003) 829; (c) C. S. Liu, P. Q. Chen, E. C. Yang, J. L. Tian, X. H. Bu, Z. M. Li, H. W. Sun, Z. Lin, Inorg. Chem. 45 (2006) 5812; (d) P. Yang, F. Cui, X.-J. Yang, B. Wu, Cryst. Growth Des. 13 (2013) 186; (e) X. Ma, L.-H. Huo, Z.-P. Deng, T.-P. Liu, H. Zhao, S. Gao, Inorg. Chem. Commun. 43 (2014) 94.

[3] (a) ) K. Singh, J.R. Long, P. Stavropoulos, J. Am. Chem. Soc. 119 (1997) 2942; (b) Q. M. Wang, T. C. W. Mak, J. Am. Chem. Soc. 123 (2001) 7594; (c) B. Liu, W. Chen, S. Jin, Organometallics 26 (2007) 3660; (d) L. Ray, M. M. Shaikh, P. Ghosh, Inorg. Chem. 47 (2008) 230; (e) X. D. Zheng, L. Jiang, X. L. Feng, T. B. Lu, Inorg. Chem. 47 (2008) 10858; (f) R. Santra, K. Biradha, Cryst. Growth Des. 10 (2010) 3315; (g) B. Li, S. Q. Zang, R. Liang, Y. J. Wu, T. C. W. Mak, Organometallics 30 (2011) 1710; (h) A. Serpe, F. Artizzu, L. Marchio, M. L. Mercuri, L. Pilia, P. Deplano, Cryst. Growth Des. 11 
(2011) 1278; (i) P.-S. Cheng, S. Marivel, S.-Q. Zang, G.-G. Gao, T. C. W. Mak, Cryst. Growth Des. 12 (2012) 4519.

[4] (a) M. A. Omary, H. H. Patterson, Inorg. Chem. 37 (1998) 1060; (b) M. L. Tong, B. H. Ye, X. M. Chen, L. N. Ji, Angew. Chem. Int. Ed. 38 (1999) 2237; (c) X. H. Bu, H. Liu, M: Du, K. M. Wong, V. W. Yam, M. Shionoya, Inorg. Chem. 40 (2001) 4143; (d) T.-L. Hu, J.-R. Li, Y.-B. Xie, X.-H. Bu, Cryst. Growth Des. 6 (2006) 648; (e) M.-S. Wang, S.-P. Guo, Y. Li, L.-Z. Cai, J.-P. Zou, G. Xu, W.-W. Zhou, F.-K. Zheng, G.-C. Guo, J. Am. Chem. Soc. 131 (2009) 13572; (f) K. Matsumoto, T. Shindo, N. Mukasa, T. Tsukuda, T. Tsubomura, Inorg. Chem. 49 (2010) 805; (g) M. Bardají, M. Barrio, P. Espinet, Dalton Trans. 40 (2011) 2570; (h) D. Pucci, A. Crispini, M. Ghedini, E.I. Szerb, M. La Deda, Dalton Trans. 40 (2011) 4614; (i) M. G. Babashkina, D. A. Safin, M. Bolte, Y. Garcia, Dalton Trans. 40 (2011) 8523; (j) A. Hameau, F. Guyon, A. Khatyr, M. Knorr, C. Strohmann, Inorg. Chim. Acta 388 (2012) 60; (k) M. Bardají, A. B. Miguel-Coello, P. Espinet, Inorg. Chim. Acta 386 (2012) 93; (1) C.F. Yan, Y.-X. Lin, F.-L. Jiang, M.-C. Hong, Inorg. Chem. Commun. 43 (2014) 19.

[5] A. Chandrasekaran, R. O. Day, R. R. Holmes, Inorg. Chem. 40 (2001) 6229.

[6] F. Mohr, M. C. Jennings, R. J. Puddephatt, Angew. Chem. Int. Ed. 43 (2004) 969.

[7] W.-K. Wong, L. Zhang, W.-T. Wong, Chem. Commun. (1998) 673.

[8] (a) Z. J. A. Komon, X. Bu, G. C. Bazan, J. Am. Chem. Soc. 122 (2000) 12379; (b) P. Barbaro, C. A. Ghilardi, S. Midollini, A. Orlandini, J. A. Ramirez, G. Scapacci, J. Organomet. Chem. 555 (1998) 255; (c) S.-M. Kuang, P. E. Fanwick, R. A. Walton, Inorg. Chem. (41) 2002 405; (d) S.-M. Kuang, P. E. Fanwick, R. A. Walton, Inorg. Chem. Commun. 5 (2002) 134; (e) W. Uhl, H. R. Bock, J. Kosters, M. Voss, Z. Anorg. Allg. Chem. 636 (2010) 1851; (f) G. Sanchez, J. Garcia, D. Meseguer, J. L. Serrano, L. Garcia, J. Perez, G. Lopez, Dalton Trans. (2003) 4709; (g) T. Schultz, A. Pfaltz, Synthesis (2005) 1005; (h) P. P. Phadnis, S. Dey, V. K. Jain, M. Nethaji, R. J. Butcher, Polyhedron 25 (2006) 87; (i) H. Schumann, H. Hemling, V. Ravindar, Y. Badrieh, J. Blum, J. Organomet. Chem. 469 (1994) 213. (j) J. S. M. Samec, R. H. Grubbs, Chem. Eur. J. 14 (2008) 2686; (k) M. Kawatsura, F. Ata, S. Wada, S. Hayase, H. Uno, T. Itoh, Chem. Commun. (2007) 298; (1) J. D. G. Correia, A. Domingos, I. Santos, C. Bolzati, F. Refosco, F. Tisato, Inorg. Chim. Acta 315 (2001) 213.

[9] (a) S.-M. Kuang, P. E. Fanwick, R. A. Walton, Inorg. Chem. 41 (2002) 1036; (b) S.-M. Kuang, P. E. Fanwick, R. A. Walton, Inorg. Chim. Acta 338 (2002) 219; (c) W. Uhl, H. R. Bock, A. Hepp, F. Rogel, M. Voss, Z. Anorg. Allg. Chem. 636 (2010) 1255; (d) J.-M. Rueff, O. Perez, A. Leclaire, H. Couthon-Gourves, P.-A. Jaffres, Eur. J. Inorg. Chem. (2009) 4870.

[10] B. P. Howe, R. V. Parish, R. G. Pritchard, Quim. Nova 21 (1998) 564.

[11] M. Pellei, G. G. Lobbia, C. Santini, R. Spagna, M. Camalli, D. Fedeli, G. Falcioni, Dalton Trans. (2004) 2822.

[12] S. J. Carlson, T. Lu, R. L. Luck, Inorg. Chem. Commun. 6 (2003) 455.

[13] CrysAlisPro Software system, Version 1.171.32; Oxford Diffraction; Oxford Ltd., Xcalibur CCD system, 2007.

[14] SHELXTL program system version 5.1; Bruker Analytical X-ray Instruments Inc.: Madison, WI, USA, 1998. 